\title{
Charles Bonnet Syndrome
}

\author{
Anthony Yao $^{1,2 *}$ and Henry Liu ${ }^{1,2}$ \\ ${ }^{1}$ Dubbo Eye Centre, Dubbo, New South Wales, Australia \\ ${ }^{2}$ Orange Eye Centre, Orange, New South Wales, Australia
}

Submission: December 01, 2017; Published: February 12, 2018

*Corresponding author: Anthony Yao, MBBS, BMedSc (Hons), Dubbo Eye Centre, 61 Wingewarra St Dubbo NSW 2830, Australia, Fax: +61 2 6885 6955, Tel: +61 26882 8460; Email: anthony.yao@gmail.com

\section{Mini Review}

“...I know a respectable man full of health, of ingenuousness, judgement and memory, who, completely alert and independently from all outside influences, sees from time to time, in front of him, figures of men, of women, of birds, of carriages, of buildings. All of this appears to have a seat in that part of the brain involved with sight. It is not difficult to imagine physical causes, strong enough to shake sensitive bundles of fibres that will produce in the mind, the picture of various objects with as much veracity as if the objects themselves had stimulated the fibres. And if the fibres used for thought are not involved but remain in their natural state, the mind will not confuse vision with reality". Charles Bonnet, "Essai Analytique sur les Faculties de L'Ame" (1760) [1].

The eminent naturalist Charles Bonnet (1720-1792) was a native of Geneva, born to a French Protestant family who fled from persecution after the St Bartholomew's Night Massacre during the French Wars of Religion [2]. Although he was originally trained in law, Bonnet's diverse interests throughout his life included botany, entomology and philosophy, and he is now most famous for being the first to describe the phenomenon of formed visual hallucinations in mentally healthy people [1].

Bonnet's initial case description stemmed from the observations of his grandfather Charles Lullin, a cognitively intact 87-year-old man whose eyesight was deteriorating several years after having undergone bilateral cataract surgery. He described remarkably detailed, silent hallucinations of figures and objects varying in size, sometimes with absurd or fantastical features, that he ultimately realised were visible only in his mind's eye and not based in reality. The variety of these images were striking, including flying handkerchiefs, well-dressed gentlemen, giant women, carriages fluctuating in size and autoscopic phenomena. Lullin found that there was no change even if he closed one eye at a time, but was convinced himself that these "visions" were related to his ailing eyesight [2].
In a radical perspective for its time, Bonnet held the view that different parts of the brain were responsible for different mental functions-and that his grandfather's experiences were the result of activity in the part of the brain responsible for vision [3]. Bonnet postulated that "his mind makes merry with the images. His brain is a theatre where the stage machinery puts on performances which are all the more amazing because they are unexpected."2Bonnet himself also suffered from failing vision, and late in life, he too experienced the same hallucinations that his grandfather had described [3].

"Any impairment of either cerebral function or peripheral input may be hallucinogenic." David Cogan, "Visual Hallucinations as Release Phenomena" (1973) [1]. The concept of Charles Bonnet Syndromerefers to abroad spectrum of visual hallucinations; its precise mechanismsremain hotly debated, but is widely accepted to be defined in part by the absence of psychopathological aetiology [4].

Clinical features typically include vivid, complex hallucinations including those of moving people, animals and vegetation, although simpler hallucinations of geometric shapes or lights can also form part of the syndrome [5]. A retrospective study at the Mayo Clinic involving 77 cases found a prevalence of complex hallucinations in $85 \%$, compared to $20 \%$ for simple hallucinations [6]. Hallucinations are usually isolated to the visual sense, with no perceptual phenomena of other sensory modalities [4]. Classically, as Bonnet described in the case of his grandfather, patients may realise that their symptomsare tricks of perception as opposed to being reality [7].

The pathophysiology of Charles Bonnet Syndrome is incompletely understood. One theory holds that abnormal signalling arises from lesions in the neurological visual pathway, and when combined with normal impulses, are ultimately manifested as hallucinations [8]. Another theory is that the excitability of neurons within the visual association cortex is 
altered by sensory deprivation, resulting in spontaneous activity that is interpreted as images [9].

There is also some controversy surrounding the pathophysiological role of impaired vision. Georges de Morsier, who named the phenomenon after Charles Bonnet in 1936, maintained that loss of vision was not necessarily integral to the development of the syndrome, citing cases where vision was recorded as normal or near-normal4. However, the majority of cases of Charles Bonnet Syndrome are reported in association with visual impairment, prominently age related macular degeneration [10]. Estimates of its incidence vary widely between $0.4 \%$ to $14 \%$ of patients attending ophthalmology clinics, largely due to variable sample characteristics and methodology [11]. A Canadian study of 258 patients of a low vision clinic, compared against 251 controls, found that Charles Bonnet Syndrome could occur in patients with visual acuities ranging from 20/40 and below-but that the risk was doubled in patients with visual acuity between $20 / 301$ and 20/800 [12].

Traditionally, Charles Bonnet Syndrome has been considered a transient, benign phenomenon that can be treated with education and reassurance. Approximately $67 \%$ of people with the syndrome may feel that it has no effect or even a pleasant effect on their quality of life. Some patients, however, may fear that they are developing a serious mental illness, may find the content of the hallucinations disturbing, or that the syndrome impedes their lifestyle [13]. There is also evidence to suggest that the syndrome may last far longer than prior estimates, with a recent study finding that $75 \%$ of participants surveyed had experienced symptoms for over 5 years [13].

Furthermore, although typical Charles Bonnet Syndrome occurs in the absence of a precipitating neuropsychiatric disease, longitudinal data suggests that a significant minority of patients eventually progress to a diagnosis of dementia [7]. One study found that approximately $26 \%$ of patients initially diagnosed with Charles Bonnet Syndrome went on to be diagnosed with some form of dementia, more commonly Lewy Body type [6]. For these patients, the initial hallucinations thought to have been part of Charles Bonnet Syndrome may instead have been reflective of subsyndromal cognitive disease.

Management of Charles Bonnet Syndrome is primarily non-pharmacological and multi-disciplinary, and includes counselling, reassurance, and reducing social isolation [8]. Avenues to restore visual function should be sought, although paradoxically, symptoms have been reported to cease entirely if visual deterioration progresses to total blindness [11]. There is limited quality evidence to guide pharmacological therapy, with scattered case reports variously using atypical antipsychotics, antidepressants, anticonvulsants and cholinesterase inhibitors.

Charles Bonnet Syndrome remains an incompletely understood phenomenon - its pathophysiology and prognosis are still evolving fields of literature. Nonetheless, the breadth of its clinical features remain essentially as described by Charles Lullin and Charles Bonnet over two and a half centuries ago. Its prevalence, especially in patients with visual compromise, means that it remains an important condition for neurologists, psychiatristsas well as ophthalmologists.

\section{Referances}

1. Hedges TR (2007) Charles Bonnet, his life, and his syndrome. Surv Ophthalmol 52(1): 111-114.

2. Draaisma D (2009) Disturbances of the Mind. In: Draaisma D (Ed.), Disturbances of the Mind. ( $1^{\text {st }}$ edn), Cambridge University Press, New York.

3. Sacks $O$ (2012) Hallucinations. In: Sacks $O$ (Ed.), Hallucinations. (1 $1^{\text {st }}$ edn), Pan Macmillan, London, UK.

4. Russell G, Burns A (2014) Charles Bonnet syndrome and cognitive impairment: a systematic review. Int Psychogeriatr 26(9): 1-13.

5. Santos-Bueso E, Saenz-Frances F, Serrador-Garcia M, Porta-Etessam J, Martinez-de-la-Casa JM, et al. (2014) Prevalence and clinical characteristics of Charles Bonnet syndrome in Madrid, Spain. Eur J Ophthalmol 24(6): 960-963.

6. Lapid MI, Burton MC, Chang MT, Rummans TA, Cha SS, et al. (2013) Clinical Phenomenology and Mortality in Charles Bonnet Syndrome. J Geriatr Psychiatry Neurol 26(1): 3-9.

7. Russell G, Harper R, Allen H, Baldwin R, Burns A, et al. (2017) Cognitive impairment and Charles Bonnet syndrome: a prospective study. Int J Geriatr Psychiatry 33(1): 39-46.

8. Schadlu AP, Schadlu R, Shepherd JB (2009) Charles Bonnet syndrome: a review. Curr Opin Ophthalmol 20(3): 219-222.

9. Pang L (2016) Hallucinations Experienced by Visually Impaired: Charles Bonnet Syndrome. Optom Vis Sci 93(12): 1466-1478.

10. Plummer C, Kleinitz A, Vroomen P, Watts R (2007) Of Roman chariots and goats in overcoats: The syndrome of Charles Bonnet. Journal of Clinical Neuroscience. 14(8): 709-714.

11. Rovner BW (2006) The Charles Bonnet syndrome: a review of recent research. Curr Opin Ophthalmol 17(3): 275-257.

12. Gilmour G, Schreiber C, Ewing C (2009) An examination of the relationship between low vision and Charles Bonnet syndrome. Can J Ophthalmol 44(1): 49-52.

13. Cox TM, Ffytche DH (2014) Negative outcome Charles Bonnet Syndrome. British Journal of Ophthalmology 98(9): 1236-1239. 


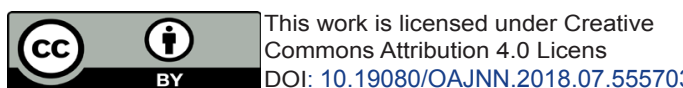

Commons Attribution 4.0 Licens

DOI: 10.19080/OAJNN.2018.07.555703
Your next submission with Juniper Publishers will reach you the below assets

- Quality Editorial service

- Swift Peer Review

- Reprints availability

- E-prints Service

- Manuscript Podcast for convenient understanding

- Global attainment for your research

- Manuscript accessibility in different formats ( Pdf, E-pub, Full Text, Audio)

- Unceasing customer service

Track the below URL for one-step submission https://juniperpublishers.com/online-submission.php 